https://helda.helsinki.fi

\title{
Erasmus and Juan Luis Vives on rhetorical decorum and politics
}

\author{
Havu, Kaarlo
}

$2021-12$

Havu , K 2021 , 'Erasmus and Juan Luis Vives on rhetorical decorum and politics ' , Historical Journal , vol. 64 , no. 5 , PII S0018246X21000078 , pp. 1151 - 1172 . https://doi.org/10.1017/S0018246X2

http://hdl.handle.net/10138/336492

https://doi.org/10.1017/S0018246X21000078

cc_by_nc_nd

acceptedVersion

Downloaded from Helda, University of Helsinki institutional repository.

This is an electronic reprint of the original article.

This reprint may differ from the original in pagination and typographic detail.

Please cite the original version. 


\title{
ERASMUS AND JUAN LUIS VIVES ON RHETORICAL
}

\section{DECORUM AND POLITICS}

\author{
Kaarlo Havu
}

University of Helsinki

\begin{abstract}
The article analyses the emergence of decorum as a central concept of rhetorical theory in the early $16^{\text {th }}$-century writings of Erasmus and Juan Luis Vives. In rhetorical theory, decorum shifted the emphasis from formulaic rules to their creative application in concrete cases. In doing so, it emphasized a close analysis of the rhetorical situation (above all the nature of the audience) and it underscored the persuasive possibilities of politeness and civil conversation as opposed to passionate, adversarial rhetoric. The article argues that the stress put on decorum in early $16^{\text {th }}$-century theory is not just an internal development in the history of rhetoric but linked to far wider questions concerning the role of rhetoric in religious and secular lives. Decorum appears as a solution both to the divisiveness of language in the context of the Reformation and dynastic warfare of the early $16^{\text {th }}$ century and as an adaptation of the republican tradition of political rhetoric to a changed, monarchical context. Erasmus and Vives maintained that decorum not only suppressed destructive passions and discord, but that it was only through polite and civil rhetoric (or conversation) that a truly effective persuasion was possible in a vast array of contexts.
\end{abstract}

In the past four decades, the rediscovery of the rhetorical dimension of Renaissance culture has been a significant breakthrough in early modern historiography. While there is hardly any field in Renaissance studies that has not been touched by this trend (philology, literature, philosophy), perhaps the most important contribution has been made in the fields of political and religious thought. Lately, several historians have argued that classical rhetoric, which recognized the possibility of competing opinions on any matter under debate, partly motivated some of the major developments of 
the era such as civic participation and the idea of religious toleration. This has challenged a classic and predominantly negative interpretation of humanist rhetoric, which stressed its aversion to serious political theory and dogmatic theology. ${ }^{1}$

Despite these developments, Renaissance rhetoric continues to pose questions regarding some of its central features. One of the most important of these concerns its internal evolution and civic potential. In many interpretations, these two issues are closely interlinked. One scholarly strand, epitomized by Quentin Skinner, has seen a great deal of continuity between classical and Renaissance rhetoric, emphasized the relative immutability of the rhetorical tradition and, more often than not, stressed the potential of Renaissance rhetoric to enhance civic participation. In this tradition, rhetoric is primarily interpreted as a humanist educational ideal and civic practice, which enabled the performance of public virtue through eloquence. ${ }^{2}$ Another line of argument, evident in Anna Bryson's From Courtesy to Civility, has identified a development in Renaissance rhetoric that slowly stripped it of its civic element. In this story, classical rhetoric was transformed into polite, decorous conversation, which, rather than enabling the political life of a citizen, dealt primarily with the delineation of social boundaries. Here the refinement of speech, often incorporated into a more

\footnotetext{
${ }^{1}$ For the history of early modern rhetoric, see Marc Fumaroli, ed., Histoire de la rhétorique dans l'Europe moderne, 1450-1950 (Paris, 1999); Brian Vickers, In defence of rhetoric (Oxford, 1988); Peter Mack, A history of Renaissance rhetoric (Oxford, 2011). For political thought and rhetoric, see Peter Stacey, Roman monarchy and the Renaissance prince (Cambridge, 2007); Peter Stacey. 'Definition, division and difference in Machiavelli's political philosophy', Journal of the History of Ideas, 75:2 (2014), pp. 189-212; Quentin Skinner, Reason and rhetoric in the philosophy of Hobbes (Cambridge, 1996); Markku Peltonen, Rhetoric, politics, and popularity in pre-revolutionary England (Cambridge, 2012). For rhetoric and theology, see Jacques Chomarat, Grammaire et rhétorique chez Érasme (2 vols., Paris, 1981); Brian Cummings, The literary culture of the Reformation: Grammar and grace (Oxford, 2007); Manfred Hoffmann, Rhetoric and theology: the hermeneutic of Erasmus (Toronto, 1994); Gary Remer, Humanism and the rhetoric of toleration (University Park, 1996). For rhetoric and philosophy, see Victoria Kahn, Rhetoric, prudence and skepticism in the Renaissance (Ithaca, 1985); Lodi Nauta, In defense of common sense: Lorenzo Valla's humanist critique of scholastic philosophy (Cambridge, MA, 2009); Peter Mack, Renaissance argument: Valla and Agricola in the tradition of rhetoric and dialectic (Leiden/New York, 1993). For rhetoric and literature, see Arthur F. Kinney, 'Rhetoric and fiction in Elizabethan England', in James J. Murphy, ed., Renaissance eloquence, (Berkeley, 1983); For rhetoric and medicine, see N. Siraisi, 'Oratory and rhetoric in Renaissance medicine', Journal of the History of Ideas, 65:2 (2004), pp. 191-211.

${ }^{2}$ Skinner, Reason; Quentin Skinner, Visions on politics (3 vols., Cambridge, 2002), pp. 2:264-85; Wayne A. Rebhorn, The emperor of men's mind, literature and the Renaissance discourse of rhetoric (Ithaca, 1995), pp. 8-9; Vickers, In defence, pp. 254-6, 268-70.
} 
general history of manners, is seen as increasingly antithetical to humanist virtue and closely associated with social control and the shaping of the self. ${ }^{3}$

In this article, I explore a third path. By looking at decorum (appropriateness, propriety) as it is developed in the rhetorical theory of Desiderius Erasmus (1466-1536) and Juan Luis Vives (1492/1493-1540), I aim to demonstrate that there was a conscious attempt to emphasize decorum and civility in the accommodation of classical rhetoric to a contemporary context, but that this development was not a denial but rather a continuation of civic ideals. I argue that this rhetoric of decorum, while imposing constraints on acceptable speech, maintained its link with the ideal of an active life in the service of the community, incorporated into itself most of the persuasive aspects of classical theory, and underscored the importance of a close analysis of one's audience as a precondition for persuasive speech. The article suggests that decorum, as it is outlined here, ultimately enables us to connect the civil with the civic.

After outlining the classical, medieval, and early Renaissance background of decorum, I will show, mainly through an analysis of Vives's De ratione dicendi (1535), that Vives's and Erasmus's rhetorical theory connected persuasion with decorous speech that was tailored for a specific audience. Next, I seek to demonstrate that their stress on decorum was not only motivated by intellectual developments, such as changes in oratorical genres or a stress put on the contextual accommodation of general rules across diverse disciplines, but that their conception of decorum was, first, an answer to the divisiveness of confrontational rhetoric in a Europe beset by the Reformation and dynastic warfare and, second, an attempt to incorporate the openly adversarial element of classical rhetoric into a princely world. Ultimately, in embedding civic participation and religious speech in civil discourse, they not only argued that division and discord could be avoided but that rhetorical persuasion could also be enhanced. The last section focuses on the broader ramifications

\footnotetext{
${ }^{3}$ Anna Bryson, From courtesy to civility: changing codes of conduct in early modern England (Oxford, 1998), pp. 15187; Keith Thomas, In pursuit of civility (London, 2018), p. 58.
} 
of decorum as a conversational virtue. I argue that decorum, which linked the avoidance of confrontation to the promise of persuasion and stability, should be seen as an original reply to a wider early modern concern with the constructive and destructive potential of speech in circumstances where the nascent pamphlet culture, religious division, and monarchical polities proposed new problems to eloquence. More specifically, I suggest that the theory of decorum had echoes throughout the early modern period in discussions on the possibilities of religious dialogue within and without Europe, and in reflections on the uses of eloquence in princely regimes.

The reason to focus on Erasmus and Vives, the most influential writers on the art of eloquence among northern humanists, is that they, despite their personal differences, shared a number of common characteristics such as a distaste for merely schematic presentations of rhetoric and a concern with the audience and decorous discourse. ${ }^{4}$ The emphasis will be on the role of their theoretical writings in the broader transformation of rhetorical theory. Consequently, I will not discuss the possible biographical motives behind these developments, and, in the case of Erasmus, I will only touch upon the tension between his stress on decorum and his often combative style of writing when he addressed his scholastic opponents. These have been treated by others elsewhere. ${ }^{5}$

The focus on the evolution of classical rhetoric to a rhetoric of decorum has some precedents the most important of which is Marc Fumaroli's work. According to Fumaroli, the rise of decorum was part of an attempt to adapt classical rhetoric into a courtly context and the new realities of civil society. I agree with Fumaroli that the emergence of decorum was not just a development in the internal history of rhetoric or in the history of manners, but that it has to be understood in the

\footnotetext{
${ }^{4}$ For Vives and Erasmus, see Charles Fantazzi, 'The Erasmus-Vives correspondence', in Stephen Ryle, ed., Erasmus and the Renaissance republic of letters (Turnhout, 2014).

${ }^{5}$ Peter G. Bietenholz, 'Ethics and early printing: Erasmus' rule for the proper conduct of authors', Humanities Association Review, 26 (1975), pp. 180-95; Perez Zagorin, Ways of lying: dissimulation, persecution, and conformity in early modern Europe (Cambridge, MA, 1990), pp. 33-4; Brian Cummings, 'Palinodiam canere: rhetoric, philosophy \& theology in Erasmus', in M. Pitassi - D. Solfaroli Camillocci, Crossing traditions: Essays on the Reformation and intellectual history (Leiden/Boston, 2018).
} 
context of changing religious and political realities. ${ }^{6}$ There are, however, also significant differences. In underlying the aesthetic dimension of decorum (the beauty of language over argumentative issues), his narrative depicts the rhetoric of decorum as a Ciceronian movement, which travels from Italian courts to the French monarchical milieu in the late $16^{\text {th }}$ century, and which is defined in opposition to a scholarly variant of rhetoric focused on things (res) over words (verba). Here Erasmus and Erasmian rhetoric is viewed either as a religious phenomenon, which centred on the translation of divine logos to human realities, or, alternatively, as scholarly speech that detested the dissimulation and adulation of the court. ${ }^{7}$

Fumaroli is undoubtedly correct in emphasizing the religious dimension of Erasmian rhetoric, which has frequently been seen as a key component of Erasmus's theory of toleration. ${ }^{8}$ While I will not omit the Christian dimension of the Erasmian rhetorical project, I seek to show that this rhetoric not only comprised a distinctively civic element since the most important rhetorical manuals, with the exception of Erasmus's Ecclesiastes (1535), were designed for practical and often civic purposes, but that a specific interpretation of decorum becomes decisively important for it. This decorum was not merely aesthetic, it was connected to a view of rhetoric that underlined the primacy of things over words, and it surely remained suspicious of the corruption of rhetoric in courtly contexts. Yet it simultaneously implied that all rhetorical tasks from argumentative invention to style should be subjected to a contextual analysis stemming mainly from one's audience, and it also suggested that in most cases an approach that hid confrontation was the best way to persuade.

\footnotetext{
${ }^{6}$ Marc Fumaroli, 'Rhetoric, politics, and society: from Italian Ciceronianism to French Classicism', in James J. Murphy, ed., Renaissance eloquence (Berkley, 1983), p. 253. See also Jennifer Richards, 'Introduction', in Jennifer Richards, ed., Early modern civil discourses (Basingstoke, 2003), p. 2. For decorum and social distinction, see Wayne A. Rebhorn, 'Outlandish fears: defining decorum in Renaissance rhetoric', Intertexts, 4 (2000), pp. 2-24; Vernon Hall Jr., 'Decorum in Italian Renaissance literary criticism', Modern Language Quarterly, 4:2 (1943), pp. 177-83. For an epistemological reading of decorum as search for truth that is embedded in time, see Victoria Kahn, Rhetoric; Stephen Pender, 'The open use of living: prudence, decorum, and the "square man", , Rhetorica: A Journal of the History of Rhetoric, 23:4 (2005), pp. 363-400. For decorum and historical interpretation, see Kathy Eden, Hermeneutics and the rhetorical tradition: chapters in the ancient legacy \& its humanist reception (New Haven, 1997), pp. 17-18, 26-8, 69-70 See also Joanne Paul, 'The use of kairos in Renaissance political philosophy', Renaissance Quarterly, 67:1 (2014), pp. 43-78.

${ }^{7}$ Marc Fumaroli, L'âge de l'éloquence (Genève/Paris, 1980), 92-113; Fumaroli, 'Rhetoric', pp. 262-4.

${ }^{8}$ Chomarat, Grammaire, pp. 1:13-25; Remer, Humanism, p. 41.
} 
Although it had a religious dimension in preaching, it was also designed for a humanist working in monarchical and princely regimes.

In Roman ethical, aesthetic, and rhetorical thought, decorum was a principle or a disposition that referred to the adaptation of one's words or actions to specific circumstances in accordance with propriety. While there was great variation in and between different disciplines as to what appropriate action/speech/writing consisted of, decorum was always thought of as a form of prudence. Consequently, decorum did not describe fixed rules designed for set situations but was an artistic principle that contained a certain degree of flexibility and indeterminacy. ${ }^{9}$

While there was a distinctively rhetorical understanding of decorum, this was certainly influenced by discussions in other disciplines. With poetic theory, as most famously expressed in Horace's Ars poetica, it shared a concern with the relationship between style and the subject matter spoken about (e.g. comic and tragic issues require a certain style), style and the person of the speaker (e.g. old men speak in a certain way), or the relationship of parts to whole in the spirit of compositional harmony and organic unity. ${ }^{10}$ From ethical theory, rhetoric adopted a strong link between inner virtue and its external manifestation in social situations. In Cicero's De officiis, the most important textbook of moral philosophy in the Renaissance, decorum meant the externalization of moral rectitude in a range of social situations and, despite of the placement of decorum within the context of aesthetic behaviour and its social judgment, it could never diverge from what was right (honestum). For Cicero,

\footnotetext{
${ }^{9}$ For the classical background of decorum and the Greek kairos, see P. Sipiora - J. S. Baumlin, eds., Rhetoric and kairos: essays in history, theory, and praxis (Albany, 2002); Robert Hariman, 'Decorum', in Thomas O. Sloane, ed., Encyclopaedia of rhetoric, vol. 1 (New York, 2001), pp. 199-209.

${ }^{10}$ Horace, Ars poetica. in Horace, Satires. epistles. The art of poetry, trans., H. R. Fairclough (Cambridge, MA, 1926), pp. 442-90, at pp. 456-61 (1.81-119).
} 
decorum not only manifested one's persona as a rational human being or as an individual, but it was also related to the ways in which one's character was shaped by external circumstances (e.g. lineage, wealth) and by one's own choice (e.g. person as a philosopher). ${ }^{11}$

While these ideals were operative in rhetorical theory, treatises by Cicero and Quintilian almost invariably described decorum as the adaptation of one's rhetoric (style but also other features) to the contextual requirements of a speaker, subject, audience, occasion, or place (the list is not exhaustive). Different treatises could, however, emphasize different terms of the list, which led to diverse interpretations of the concept. Broadly speaking, there were two possibilities that partly reflected the Greek distinction between prepon (propriety, appropriateness) and kairos (occasion, the right time to do something), both of which could be part of the semantics of the Roman decorum. ${ }^{12}$ First, the stress put on the accommodation of one's style to the subject spoken about (central for instance in Cicero's De oratore) or the adaptation of one's rhetoric to the age and social rank of the speaker (as in Cicero's Orator) underlined the general social conventions that fed into rhetorical choices. ${ }^{13}$ The second approach to decorum stressed more its capacities to facilitate persuasion in concrete situations. When this was the case, the balance shifted towards an analysis of the radically particular features of the speech stemming from the location and time (kairos) or to a more detailed inspection of the expectations of one's audience. In Quintilian's Institutio oratoria, decorum is largely adopted into a persuasive framework in which the analysis of the opinions and nature of one's particular audience (often the judge in legal cases) was connected to stylistic and other rhetorical

\footnotetext{
${ }^{11}$ Cicero. De officiis, trans., W. Miller (Cambridge, MA, 2005), pp. 94-121 (1.27.93-1.32.117).

${ }^{12}$ For a distinction between ethical decorum and more opportunistic kairos, see Paul, 'kairos', pp. 43-4. For an interpretation that shows how Latin decorum combined meanings from prepon and kairos, see James Baumlin, 'Ciceronian decorum and the temporalities of Renaissance rhetoric', in Sipiora - Baumlin, eds., Rhetoric, p. 159; James Kinneavy, 'Kairos: a neglected concept in classical rhetoric', in J. Deatz Moss, ed., Rhetoric and praxis: the contribution of classical rhetoric to practical reasoning (Washington DC, 1986), p. 82.

${ }^{13}$ Cicero, De oratore I-III, trans., E. W. Sutton - H. Rackham (2 vols., Cambridge, MA, 1942), pp. 1:100-1, 2:166-9 (1.32.144, 3.60.210-212); Cicero. Orator, trans., H. M. Hubbell, in Cicero, Brutus - Orator (Cambridge, MA, 1939), pp. 306-509, at pp. 356-61 (21.69-22.74).
} 
choices. Here decorum does not so much strengthen social discipline but serves as a creative principle of rhetorical persuasion in a concrete case. ${ }^{14}$

Some of the classical advice on decorum, such as the litany of contextual requirements, was integrated in medieval rhetorical theory centered on poetry, letter writing, and preaching. ${ }^{15}$ With its rule-based structure, the medieval tradition, however, rarely expanded on decorum, and when it did so, it focused more on the production of socially accepted language in poetry and epistles than on persuasion in particular situations. While the emergence of humanist handbooks on rhetoric in the $15^{\text {th }}$ century introduced several new stylistic ideals, rhetorical manuals continued to portray the art of eloquence predominantly as a schematic art. Popular Italian letter-writing manuals and the bulk of rhetorical handbooks preceding Erasmus in transalpine Europe, such as Johannes Despauterius's (c.1460-1520) works, offer very little about decorum or about the contextual accommodation of one's rhetoric to the particularities of a situation stemming from the audience, time, or place. Even when one looks at Erasmus's contemporaries, decorum is largely absent. Philipp Melanchthon (14971560), the most important writer on the art of eloquence in the Reformed circles, was familiar with decorum but did not include an important section on the concept to any of the three versions of his handbook of rhetoric. ${ }^{16}$

There are, however, some developments in $15^{\text {th }}$-century rhetorical theory that might have inspired Erasmus's and Vives's conception of decorum, although they are not directly quoted in the most significant sections on decorum. First, through George of Trebizond's (1395-1486) oftenprinted Rhetoricorum libri V (1433/1434), Hermogenes' complex discussion of style, practically unknown in the West before the $15^{\text {th }}$ century, was introduced into rhetorical theory. This tradition

\footnotetext{
${ }^{14}$ Quintilian. Institutio oratoria, trans., D. A. Russell (5 vols., Cambridge, MA, 2001), pp. 1:341, 5:8-59 (2.13.2-3, 11.1.1-11.1.93).

${ }^{15}$ Geoffrey of Vinsauf, Poetria nova, trans., Margaret Nims (Toronto, 2010), pp. 72-4; David Mañero Lozano, 'Del concepto del decoro a la "teoría de los estilos", Bulletin hispanique, 111-2 (2009), pp. 357-85, at p. 369-72; David Scott Wilson-Okamura, Virgil in the Renaissance (Cambridge, 2010), pp. 90-3.

${ }^{16}$ Philipp Melanchthon, Institutiones rhetoricae, in Melanchthon, Opera omnia: Opera philosophica. Part 2, Principal writings on rhetoric, eds., Weaver - Strohm - Volkhardt (Berlin, 2017), pp. 211-54, at p. 221; Philipp Melanchthon, Elementorum rhetorices libri duo, in Melanchthon, Opera, pp. 269-408, at p. 328.
} 
emphasized the contextual accommodation of style to a great degree. Hermogenes, very much drawing on prepon, had argued that the use of a vast array of styles was mediated through deinotēs (force), a general standard of contextual accommodation the mastery of which made one 'the most forceful of orators'. ${ }^{17}$ Trebizond's Rhetoricorum libri $V$ also claimed, in the spirit of deinotēs, that true gravity in a speech could only be achieved through an adaptation of one's style to the demands of a particular situation. ${ }^{18}$ While contextual adaptation here referred primarily to stylistic concerns, it could include more complex argumentative issues as well with Hermogenes claiming, in the part on deinotēs, that part of 'the essence of true force' was 'to know what kind of proofs and thoughts are suitable in the proemium [introduction] or in the narration or in the conclusion' ${ }^{19}$ Trebizond's treatise and the Hermogenean tradition were known in the early $16^{\text {th }}$ century and incorporated into rhetorical curricula in works such as Vives's De disciplinis. ${ }^{20}$

Another source that was highly considered by the Erasmian circles was Rudolph Agricola's (1443/1444-1485) De inventione dialectica (first printed in 1515), which combined subject matter from the dialectical and rhetorical traditions. While Agricola did not elaborate on decorum as such, he aspired to provide a flexible alternative to the formulaic understanding of eloquence propounded in rhetorical handbooks. He did this by showing how questions (quaestio) could be handled in front of a particular audience with specific expectations in concrete situations. More than standard rhetorical theory, this invited one to think about the particularities of the audience and the situation. ${ }^{21}$

\footnotetext{
${ }^{17}$ Hermogenes, On types of style, trans., C. W. Wooten (Chapel Hill: University of North Carolina Press, 1987$)$, p. 101.

${ }^{18}$ George of Trebizond, Rhetoricorum libri, in quibus quid recens praestitum, proxima facie indicabit liminaris epistola (Basel, 1522), fos. 164r-7r.

${ }^{19}$ Hermogenes, Style, pp. 101.

${ }^{20}$ John Monfasani, 'The Byzantine rhetorical tradition and the Renaissance', in James Jerome Murphy, ed., Renaissance eloquence: studies in the theory and practice of Renaissance rhetoric (Berkeley, 1983), pp. 182-3; Juan Luis Vives, De disciplinis: Savoir et enseigner, trans., and ed., T. Vigliano (Paris, 2013), pp. 388, 401, 402.

${ }^{21}$ While the focus of De inventione dialectica is on the topical analysis of questions, Book 3 deals with the emotions and with the rhetorical goals of moving and pleasing; Rudolph Agricola, De inventione dialectica libri tres (Tübingen, 1992), pp. 228-98 (2.6-2.14), 280-3 (2.13), 440-1 (3.2.26-31), 446-7 (3.3.36-46). See also Mack, Renaissance argument, pp. 181-9, 203-18.
} 
In his 1535 De ratione dicendi, Juan Luis Vives made extraordinary claims concerning the importance of decorum for rhetorical theory. As Peter Mack has stated, Vives's handling of decorum was the most extensive treatment of the topic since Quintilian's Institutio oratoria and clearly at odds with the standard rhetorical theory of the time. ${ }^{22}$ Vives made two crucial points concerning decorum. First, he argued that decorum was not just one element of rhetoric, but that rhetoric was an art of decorum since all linguistic composition was ultimately mediated through it. Concerning its mediating function, Vives tells us three things in the introduction but also in other parts; decorum is the principal issue of the art of rhetoric, that one acquires decorum through experience and prudence rather than technical precepts, and that decorum deals primarily with the accommodation of one's speech to the contextual requirements of the situation. As he put it, since decorum is 'the essential part' of the art, it 'cannot be taught' because it does not belong to rhetoric but to 'life'. Because it is a form of prudence and deals with 'particular things' concerning 'things, persons, places, times', it 'cannot he condensed into precepts'. ${ }^{23}$

While Vives, like Cicero, saw decorum as an element of one's character and not just as a technical skill, he still offered some rule-based instruction. As his second main point, Vives maintained that the key to decorum lay principally on one's audience rather than on the speaker or the subject matter. While the litany of contextual requirements was preserved and while Vives

\footnotetext{
${ }^{22}$ Peter Mack, 'Vives's De ratione dicendi: structures, innovations, problems', Rhetorica: A Journal of the History of Rhetoric, 23:1 (2005), pp. 65-92, at pp. 84-5; Peter Mack, 'Vives's contributions to rhetoric and dialectic', in Charles Fantazzi, ed., A Companion to Juan Luis Vives (Leiden/Boston, 2008), p. 238.

${ }^{23}$ Juan Luis Vives, Del arte de hablar, ed., J. M. Rodríguez Peregrina (Granada, 2000), p. 100: 'Caput artis dicunt esse decere quod facias, atque id unum esse quod tradi non possit, quod non tam es huius artis proprium quam vitae totius; itaque prudentiae est, quae praeceptis contineri nequit, nempe sigularum rerum, quaeque spectat res, personas, loca, tempora'. All the translations from Vives's De ratione dicendi are mine.
} 
amplified on the link between persons, subject matter, and style, he ultimately considered the analysis of one's audience to be the most important one for most rhetorical choices. ${ }^{24}$ The idea that considerations of the audience should play a role in rhetorical composition was not completely new. In standard theory, audiences were usually conceptualized through the dichotomies of learned/unlearned and opposed/benevolent to our cause each of which required its own treatment. For instance, in the Ad Herennium, a widely-used elementary introduction to rhetorical theory, the reader was told that a subtle approach to the introduction of the speech (exordium) was needed when the audience was opposed to what we were saying because they had been convinced by a previous speaker. ${ }^{25}$ But apart from specific rhetorical tasks such as the exordium, the audience was not a central category of classical rhetorical theory.

In De ratione dicendi, the importance of the audience was taken much further. In the part on decorum, we are presented with a number of headings for the analysis of the audience (ingenium, eruditio, memoria, aetas, mores) and detailed advice is given on how to overcome the resistance of the audience resulting from lack of attention (attentio), from their natural talent (ingenium), or from their emotional dispositions (affectus) throughout the speech. ${ }^{26}$ This advice, partly connected with the arrangement of the speech, was coupled together with a more striking call to imagine the opinions and emotional attitudes of our audience as a key to the moving of their emotions. We are told to 'put ourselves into their position' and to consider the nature of our audience, what is 'their judgment of things', what 'emotions are they prone to', and 'from what emotions they move to other emotions easily' due to their 'character, convictions, habits, age, sex, health, appearance, position', and other issues. ${ }^{27}$ In addition to style, decorum clearly concerned

\footnotetext{
${ }^{24}$ Vives, hablar, pp. 101-4, 111-13.

${ }^{25}$ Ad Herennium. trans., H. Caplan (Cambridge, MA, 1954), pp. 16-18 (1.5.8).

${ }^{26}$ Vives, hablar, pp. 116-23.

${ }^{27}$ Ibid., p. 91: 'Ante omnia considerandum qui nos simus, qui illi quos agitare volumus aut sedare, quod eorum iudicium de rebus, quibus plurimum tribuunt, quibus parum, in quos affectus sint proclives, a quibus alieni, ex quibus in quos leviter transeant, ex ingenio, persuasionibus, moribus, aetate, sexu, valetudine, habitudine, conditione ... Induenda mens illorum et totum ingenium tantisper, dum quae ad rem nostram faciant excogitamus; ponamusque nos illorum loco $\ldots$...
} 
argumentation since part of the adaptation of one's message to a specific audience happened by emphasizing the aspects of the issue at hand that spoke to the emotional dispositions of the audience. ${ }^{28}$

As we will see, De ratione dicendi condensed into precepts much of Vives's and Erasmus's earlier reflections on the art of eloquence. These stemmed from three sources: firstly, reasons related to rhetorical genres; secondly, general intellectual reasons linked to the historization of the rhetorical canon; and thirdly, the dynamics of religious and political discussions in the $1520 \mathrm{~s}$ and 1530s. In the following sections, we must take a closer look at all three.

\section{III}

While Vives's De ratione dicendi was not devised for a specific rhetorical genre, the most popular humanist manuals were designed for applied genres of rhetoric. Letter writing was perhaps the most important of these, and both Erasmus and Vives composed highly popular letter-writing manuals entitled De conscribendis epistolis (Erasmus, 1522) and De conscribendis epistolis (Vives, 1536). Now what distinguishes letter writing from classical rhetorical genres (judicial, deliberative, demonstrative) was not only its literary nature but the fact that epistles, at least those not written for publication, were targeted for one recipient. It is in some sense natural that whereas the larger audiences of public oratory could not be analysed in any detail and had to be classified according to general typologies, the inspection of one recipient could be more meticulous.

The importance of the analysis of the audience was indeed stressed in Erasmus's and Vives's letter-writing manuals. With Erasmus, we can even detect a shift from his Conficiendarum epistolarum formula (printed in 1520), a work that has been described as a sketchy attempt based on

\footnotetext{
${ }^{28}$ See for instance Ibid., pp. 123-5.
} 
some of Erasmus's early notes, to his more complete De epistolis conscribendis. ${ }^{29}$ In Formula, the presentation was built around traditional rhetorical theory, namely the three genres of oratory (judicial, demonstrative, deliberative), under which different kinds of letters were placed. Simultaneously, however, Erasmus called for prudential judgment and flexibility in using artistic precepts mentioning many of the contextual elements often placed under decorum (case, times, occasion, necessity). More importantly, he considered this accommodation especially crucial in letter writing since letters were destined to 'men of different origin, rank, and temperament in different times and different places'. ${ }^{30}$ In De conscribendis epistolis, the centrality of the audience was frequently stressed and tied together with persuasive speech. As a general advice, Erasmus told his readers that they 'should not at once have recourse to rules nor take refuge in books from which they may borrow elegant little words and sententious expressions'. Rather, the student should survey carefully the topics and familiarize himself with 'the nature, character and moods' of the recipient as well as to consider one's own relationship to him. From this examination, one should draw 'the living model of the letter'. ${ }^{31}$ In Vives's De conscribendis epistolis one finds similar concern with the nature of the recipient. Vives instructed the reader to consider the person of the recipient since 'this will set the tone for the whole letter' and built entire sections of the work primarily on a close analysis of the audience. $^{32}$

It would, nevertheless, be a mistake to consider the generic importance of letter writing to be the sole reason for the focus on decorum interpreted through the audience. After all, letter writing (ars dictaminis) had been an important genre of applied rhetoric throughout the middle ages but this tradition, apart from advice concerning a proper salutation (salutatio), had not attributed to the detailed analysis of the recipient anything even closely resembling the importance that one finds

\footnotetext{
${ }^{29}$ Sowards, 'Introduction', CWE 25, pp. ix-lix, at pp. li-lii. All references to works by Erasmus follow the collected editions using the standard abbreviations: CWE Collected works of Erasmus (72 vols., Toronto, 1974-); ASD Opera omnia (9 vols. in parts, Amsterdam, 1969-). All translations of Erasmus are from CWE.

${ }^{30}$ CWE 25, p. 261 (Conficiendarum epistolarum formula).

${ }^{31}$ ASD I/2, p. 316 (De conscribendis epistolis, CWE 25, p. 74).

32 Juan Luis Vives, De conscribendis epistolis, ed., Charles Fantazzi (Leiden, 1989), pp. 34-5, 51-65. See also 28-9.
} 
in Erasmus and Vives. ${ }^{33}$ Indeed, in order to understand the emphasis put on decorum and the audience, one has to consider two intellectual tendencies. These were the relative historization of the rhetorical canon inherited from classical antiquity and the pronounced stress put on to the analysis of particularities in place of general rules across different intellectual disciplines (e.g. jurisprudence, theology, ethics).

The way in which humanist philology contributed to an idea of a temporal difference to the literary monuments of antiquity is well known. ${ }^{34}$ But there were more specific debates in the field of rhetoric the most famous of which concerned the proper imitation of Cicero, the most revered authority in rhetoric. In this debate, which had originated in quattrocento Italy, Erasmus, supported by humanists such as Vives, took on a strong strand of Italian and French humanists who called themselves Ciceronians. Erasmus's major contribution to the debate was a work entitled Ciceronianus (1528). ${ }^{35}$ In Ciceronianus, Erasmus painted a caricature of a Ciceronian (Nosoponus), who dedicated himself to the imitation of one model, Cicero, and understood imitation to refer to an exact reproduction of Cicero's words, characteristic expressions, and rhythmical patterns. ${ }^{36}$ In delineating his answer to Nosoponus with the mouth of Bulephorus, Erasmus made numerous critical points against servile imitation and presented his own theory of flexible imitation or emulation, but for our present purposes it suffices to notice that much of Erasmus's argument was based on reading Cicero as an example of decorum. Erasmus discussed rhetoric primarily as a persuasive and useful practice and explicitly called a Ciceronian a person who spoke 'clearly, richly, and appropriately, in keeping with the nature of his subject, and with the circumstances of the times and of the persons involved'. ${ }^{37}$ Moreover, Erasmus foregrounded the persuasive element of Cicero's speech and considered it a key-

\footnotetext{
${ }^{33}$ James J. Murphy, Latin rhetoric in the middle ages (Aldershot, 2006), pp. I:13-16.

${ }^{34}$ John D'Amico, Theory and practice in Renaissance textual criticism: Beatus Rhenanus between conjecture and history (Berkeley, 1988), pp. 1-7; Luca Bianchi, 'Continuity and change in the Aristotelian tradition', in James Hankins, The Cambridge companion to Renaissance philosophy (Cambridge, 2007), pp. 54-9.

${ }^{35}$ For Ciceronianus, see Knott, 'Introductory note', in CWE 28, pp. 324-36, at pp. 324-7.

${ }^{36}$ See for instances ASD I/2, p. 609 (Ciceronianus).

${ }^{37}$ ASD I/2, pp. 650 (Ciceronianus. CWE 28, p. 400), 654. See also Eden, Hermeneutics, PP. 69-70.
} 
component of decorum and good rhetoric. ${ }^{38} \mathrm{He}$ also clearly maintained that in order for rhetoric to retain its persuasive element, Cicero and the rhetorical tradition should be accommodated to changed circumstances in the spirit of decorum.

The other tendency concerned the propensity to stress the particularities of a given situation across the gamut of disciplines. The idea that general rules always needed accommodation to a context is at the very heart of Erasmus's and Vives's rhetorical theory. In Formula, Erasmus argued that to write merely according to prescriptions lacked in effectiveness and that 'there is need of practical wisdom, which is the partner or parent of technique'. ${ }^{39}$ Vives, in De conscribendis epistolis, also told his readers to consider as our 'first rule' that formulas facilitate invention 'but that they will have no effect of themselves unless they are joined with experience and practice'. ${ }^{40}$

The contextual accommodation of general rules was truly central for the humanist understanding of most disciplines dealing with human affairs. In ethics, theology, and legal studies, Erasmus and Vives frequently underscored that these disciplines could not be condensed into fixed rules but were largely based on the prudential ability to accommodate general guidelines to specific circumstances. This underscored the role of persona in all human affairs; rules were helpful only if they had become part of one's predisposition to judge correctly. In law, to take an example, both emphasized the virtuous interpretation of general rules according to particular situations by referring to the concept of fairness (aequitas, epikeia). Vives's main point throughout his texts on jurisprudence was to argue for the Aristotelian idea, according to which the plurality of individual cases was such that they could not be condensed into general rules and hence had to be judged in the spirit of epikeia. ${ }^{41}$ Just like epikeia was understood as a prudential activity, decorum in rhetoric, often likened to prudence, dealt as a mediator between general rules and the particularities of a situation. A person

\footnotetext{
${ }^{38}$ ASD I/2, pp. 654, 702-3 (Ciceronianus); ASD I/2, pp. 222-3 (De conscribendis epistolis).

${ }^{39}$ CWE 25, p. 261 (Formula).

${ }^{40}$ Vives, De conscribendis, pp. 26-7.

${ }^{41}$ Juan Luis Vives, Aedes legum, in Vives, Opera omnia, vol. 1 (Basel, 1555), pp. 301-6, at pp.

305-6; ASD IV/1, pp. 194-204 (Institutio principis Christiani).
} 
who had interiorized decorum could mould the information of rhetorical theory and wisdom into the contextual requirements of any situation so that socially accepted rules were not violated and persuasion was facilitated.

\section{IV}

The general intellectual reasons outlined above and the move from public oratory to letter writing have some explanatory force. Intellectual developments provide a context for understanding why Erasmus and Vives were receptive to a tradition that had emphasized decorum and contextual accommodation in place of general rules. The stress on genres in which one was addressing just one person explains why the focus within the contextual litany of decorum was centred on the recipient, but it perhaps does less to clarify why decorum was considered of decisive importance in forms of public speaking as well (e.g. preaching). Neither accounts for a central feature of decorum, namely the acceptance of socially accepted rules and hierarchies as a precondition for a truly persuasive speech in all possible genres. This is a complex issue since much of Erasmus's (and to a lesser extent Vives's) writing is strikingly licentious in its treatment of secular and religious authorities, as epitomized by Moriae encomium (1511).

A comprehensive analysis of the chronological evolution of Erasmus's position on licentiousness, dissimulation, and decorum, and of the tension between Erasmus's theoretical position on civil discussion and his own practice cannot be offered here. ${ }^{42}$ It seems to be clear, however, that Erasmus, especially in his theoretical writings, gradually moved to a position that emphasized restrained speech that would hide open confrontation at least partially as a reaction to the dynamics of public discussion of the time unleashed by Martin Luther (1483-1546). Especially in the 1520s,

\footnotetext{
${ }^{42}$ See note 5 .
} 
Luther and his followers produced an unprecedented number of texts (treatises and pamphlets) many of which were openly polemical towards the existing ecclesiastical and political establishment. ${ }^{43}$ While Erasmus never completely abandoned his combative style in his controversies with the scholastics, he developed a nuanced understanding of the importance of dissimulation and rhetorical decorum in his Biblical exegesis and rhetorical writings as a reply to Luther. This idea often concerned specific Biblical passages - most famously Galatians 2:11-14 which had been fiercely debated already by Jerome and Augustine - and it was epitomized by the apostle Paul. Although Erasmus's interest in Paul and dissimulation preceded the rise of Luther as a threat to the unity of the church, Paul became perhaps the central figure in Erasmus's criticism of Luther at the turn of the 1520s. ${ }^{44}$ Indeed, when Erasmus gradually turned against Luther after a period of initial excitement, he did not focus his criticism on Luther's doctrinal mistakes but on Luther's (and his followers') aggressive speech, a point that did not escape those who were favourable to Luther. ${ }^{45}$

One of Erasmus's most important expositions of the decorum of Paul and criticism of Luther happened in a printed letter (1521) to Justus Jonas (1493-1555), who was wavering between Erasmus's humanism and Luther's Reformation. Here Erasmus expanded on the 'courtesy and meekness' of Gospels in propagating truth, addressed Christ's ability to speak differently to his disciples and to the multitude, and praised Paul's ability 'to become all things to all men' which enabled him to win over souls. ${ }^{46}$ In contrast, Erasmus elaborated on Luther's faults. He complained about Luther's 'freedom of invective against the Roman pontiff, against all the universities, against philosophy, against the mendicant orders' and reminded Jonas that 'since truth of itself has a bitter taste for most people ... it would have been wiser to soften a naturally painful subject by the courtesy

\footnotetext{
${ }^{43}$ Andrew Pettegree, 'Books, pamphlets and polemic ', in Andrew Pettegree, ed., Reformation World (London, 2000), pp. 110-11.

${ }^{44}$ Peter G. Bietenholz, 'The patristic controversy about Galatians 2.11-14 and the reaction of Erasmus of Rotterdam', Shingaku-kenkyu, 50 (2003), pp. 171-83; Bietenholz, 'Ethics', pp. 142-7.

${ }^{45}$ Allen 1374, 5, p. 304 (Wolfgang Capito to Erasmus, CWE 10, p. 46). All references to Erasmus's letters are taken from Erasmi Epistolae, eds., P. S. Allen and H. Allen (12 vols., Oxford, 1906-58), using the abbreviation Allen, the number of the letter, the volume, and the pages in question.

${ }^{46}$ Allen 1202, 4, p. 488 (Erasmus to Justus Jonas, CWE 8, pp. 203, 204).
} 
of one's handling than to pile one cause of hatred on another' ${ }^{47}$ Because Erasmus's main complaint concerned Luther's aggressive tone, it is hardly a surprise that Erasmus, in the public debate on free will, proposed a friendly philosophical conversation (diatriba) as a civil way to solve the dispute in his De libero arbitrio (1524). As is well known, Luther rejected this invitation and resorted to a more confrontational language. ${ }^{48}$ Erasmus's most extensive treatment of decorum in his opus magnum Ecclesiastes on the rhetorical genre of preaching also drew significantly on his theory of dissimulation incarnated in the Apostle Paul. ${ }^{49}$ In this way, decorous rhetoric that respected its audience and tolerated its possible errors was seen as a precondition for a truly transformational speech.

But Erasmus's ideals of dissimulation and decorum were by no means restricted to preaching or religious discussions. In fact, Erasmus emphasized the importance of decorum in all forms of speech, ranging from scholarly discussion to civic rhetoric destined to secular rulers. The focus on secular rhetoric is visible in his reflections on language, on changed political circumstances, and on his views on how to address rulers. In a dedication letter to Lingua (1525) on the sins of the tongue, Erasmus complained that an unbridled tongue, the most severe of mind's diseases, had 'infected the whole world ... the courts of the princes, the homes of the commoners, theological schools, monastic brotherhoods, colleges of priests, regiments of soldiers, and the cottages of peasants'. He proceeded to argue that this disease threatens 'liberal arts, good morals, civic harmony, and the authority of the leaders of the Church and the princes of the realm alike'. ${ }^{50}$ In expanding on how the vices of tongue had poisoned the minds of men by addressing destructive passions, Erasmus frequently linked this to print culture. He described how scandalous and anonymous pamphlets had aggravated the problem by spreading the poison. ${ }^{51}$ Furthermore, Lingua pointed out that an unbridled

\footnotetext{
${ }^{47}$ Allen 1202, 4, p. 487 (Erasmus to Justus Jonas, CWE 8, pp. 202, 203).

${ }^{48}$ For more about Erasmus's choice of genre, see Marjorie O'Rourke Boyle, Rhetoric and reform: Erasmus' civil dispute with Luther (Cambridge, MA, 1983); Remer, Humanism, pp. 81-4, 92-7.

${ }^{49}$ ASD V/5, pp. 288-308 (Ecclesiastes).

${ }^{50}$ ASD IV/1a, pp. 22 (Lingua, CWE 29, pp. 259-60). See also ASD V/5, pp. 302 (Ecclesiastes).

${ }^{51}$ ASD IV/1a, pp. 116-7, 127, 130 (Lingua).
} 
tongue, with its criticism of secular rulers, should not foster anarchy and rioting. ${ }^{52}$ Similar concern with adversarial speech surface in Vives's writings such as De concordia et discordia in humano genere (1529). ${ }^{53}$ Vives, the writer of the satirical In pseudodialecticos against the scholastics in 1519 , also came to gradually underline the importance of avoiding confrontational speech and adopted sine querela (without quarrel) as his motto in the $1520 \mathrm{~s}^{54}$

The complaint about the divisiveness of open confrontation coincided with a recognition that politics had largely moved from public oratory and the forum to more private settings. In Vives's De consultatione (printed in 1533), which adapted deliberative (political) rhetoric to the practice of counsel, we are reminded that addressing a prince was distinctively different from the republican debates of classical antiquity where the parity of citizens in the senate allowed liberty of speech. ${ }^{55}$ Erasmus's Ciceronianus, while primarily an attempt to adapt pagan rhetoric to a Christian world, referred also to changed political circumstances. Erasmus maintained that a speech modelled closely on Cicero would lack persuasive power in present-day law courts, council-chambers, administration, in addressing the broader public, and in most epistolary discussions. He argued that while Ciceronian speech could be of some ceremonial use for a diplomat addressing an Italian audience (preferably in Rome), it was irrelevant for the conduct of serious political affairs which 'is dealt with in private, through letters and conversations in French' ${ }^{56}$

Their discourse on political counsel also underscored the private element of politics in describing the relationship between the counsellor and the prince as a form of friendship (amicitia),

\footnotetext{
52 Ibid., p. 102.

${ }^{53}$ Vives, Opera omnia, ed., Gregorio Mayans y Siscar. (8 vols., Valencia, 1782-90, hereinafter Mayans), pp. 5:233, 247 (De concordia).

${ }^{54}$ Enrique González González, 'Vives: un humanista judeoconverso en el exilio de Flandes', in Dequeker - Verbeke eds., The expulsion of the Jews and their emigration to the Southern Low Countries (15th - 16th C.) (Leuven, 1998), p. 81; Enrique González González, Una república de lectores. Difusión y recepción de la obra de Juan Luis Vives (México, 2007). pp. 54-6

${ }^{55}$ Vives, De consultatione liber I, in Vives, Rhetoricae, sive de recte dicendi ratione libri tres, Eiusdem de consultatione liber I (Basel, 1536), pp. 233-72, at p. 250.

${ }^{56}$ Erasmus, ASD I/2, pp. 653-5 (Ciceronianus. CWE 28, p. 406). For the Christian dimension of the work, see esp. Ibid., pp. 599-600.
} 
which is why oratorical advice was largely accommodated to informal conversation (sermo) in place of public oratory (oratio). Vives's De consultatione on princely counsel employed friendship (amicitia) for one of Aristotle's three sources of ethos (eunoia/benevolentia), and, just as Aristotle's eunoia, the concept highlighted the importance of the specific relationship between the speaker and the audience for successful persuasion. ${ }^{57}$ In Institutio principis Christiani (1516), Erasmus claimed that the 'citizens who are distinguished for their moral quality, judgment, and prestige' should be considered as friends by a good king who welcomes all advice and 'likes friends who speak frankly'. ${ }^{5}$ Erasmus's Institutio was often printed with Plutarch's De discrimine adulatoris \& amici (How to Tell a Flatterer from a Friend), which explicitly likened good counsellors to friends. The relevance of friendly conversation was, in addition to counsel, apparent in letter-writing manuals, which were typically, following Cicero, placed within the tradition of conversation (sermo) rather than rhetoric (oratio) ${ }^{59}$

Erasmus has sometimes been said to embody the ideals of humanist counsel which, unlike flattery, was based on free speech and parrhesia. ${ }^{60}$ But although Erasmus could connect friendly advice with frank speech and although he portrayed the corrupted counterpart of a counsellor as a flatterer whose words did not reveal his true intentions, he provided a great deal of information on how to mould one's argument according to the recipient. Indeed, the stress put on the recipient in his and Vives's letter-writing manuals and in Vives's De consultatione dealt abundantly, if not primarily, with situations in which one addressed those who were above oneself in the social hierarchy. In Erasmus's De conscribendis epistolis, the most glaring example of this was false praise which was said to enable the persuasion of those above us because it suppressed open confrontation. Concerning letters of advice, Erasmus suggested that 'we shall mitigate the harshness of criticism

\footnotetext{
${ }^{57}$ Vives, De consultatione, pp. 244, 247

${ }^{58}$ ASD IV/1, pp. 154-6 (Institutio principis Christiani, CWE 27, p. 224)

${ }^{59}$ Vives, De conscribendis, p. 22; ASD I/2, pp. 210, 215-16 (De conscribendis epistolis).

${ }^{60}$ Jacqueline Rose, 'Kingship and counsel in early modern England', The Historical Journal, 54:1 (2011), pp. 47-71, at pp. 49-50; John Guy, 'The rhetoric of counsel in early modern England', in Dale Hoak, ed., Tudor political culture (Cambridge, 1995).
} 
with praise'. A criticism of 'a ruler or king or some other potentiate' should be conducted through 'false praise' because their 'ears will not tolerate any criticism at all' ${ }^{61}$ In Lingua, he described appropriateness as 'the first merit of speech' and gave numerous examples of how to approach rulers so that the 'bitterness of truth' was 'diluted with great sweetness of tongue'. ${ }^{62}$

The role of praise in princely counsel was already part of Erasmus's repertoire in an early piece of epideictic rhetoric composed for the Archduke Philip (1478-1506) entitled Panegyricus (1504). In defending the adulatory tone of the piece against his critiques, Erasmus systematically argued that it was precisely through praise that a serious message could be communicated to princes, a point that was reiterated in his letters and in Institutio principis Christiani.${ }^{63}$ In addition to the ideally transformational potential of epideictic rhetoric to motivate character formation, praise was also part of deliberative rhetoric in De conscribendis epistolis. Erasmus claimed that many central letter types - such as conciliation, reconciliation, encouragement, discouragement, persuasion, dissuasion, consolation, petition, recommendation, admonition, and the amatory letter - were part of the deliberative genre. ${ }^{64} \mathrm{He}$ differentiated between persuasive letters that changed the recipient's way of thinking and letters of encouragement that produced 'courage to act' but underlined their overlapping and similarity to a great deal. ${ }^{65} \mathrm{He}$ also characterized praise as an 'instrument of encouragement' and elaborated on how the praise of the subject or the recipient served as an incentive to action. ${ }^{66}$ In a similar vein, Erasmus described how emotions such as hope, fear, love, hatred, or pity functioned as impetus to act; when one depicted the consequences of a suggested course of action so that they spoke to the emotional dispositions and expectations of the recipient, one encouraged or discouraged one's audience from the action in question. Both praise and the use of emotions were systematically linked

\footnotetext{
${ }^{61}$ ASD I/2, p. 488 (De conscribendis epistolis, CWE 25, p. 189).

${ }^{62}$ ASD IV/1a, pp. 60-2 (Lingua, CWE 29, pp. 294-5). See also David Rundle, 'Erasmus, panegyric, and the art of teaching princes', in Yun Lee Too - Niall Livingstone, eds., Ideology and Power (Cambridge, 1998).

${ }^{63}$ Allen 179, 1, p. 397 (Erasmus to Nicholas Ruistre); Allen 180, 1, p. 399 (Erasmus to Jean Desmarais); ASD IV/1, p.

154 (Institutio principis Christiani).

${ }^{64}$ ASD I/2, pp. 310-11 (De conscribendis epistolis).

${ }^{65}$ Ibid., pp. 315-316 (CWE 25, p. 73).

${ }^{66}$ Ibid., pp. 324-325 (CWE 25, pp. 79-80).
} 
to an analysis of one's recipient, since, concerning praise, 'much depends on personal character', whereas the arousal of fear and hope only worked if 'we have perceived what affects each person' ${ }^{67}$

Similar issues were taken up in Vives's De conscribendis epistolis. Just as in Erasmus, praise was described as 'an incentive to virtue' and Vives elaborated at length on its possibilities and threats in approaching those in power who 'do not tolerate an open reproof' ${ }^{68}$ Praise was, however, merely one element of a rhetoric of decorum. In Vives's De conscribendis epistolis, we are told that since the letters that treat issues pertaining to the addressee (instruction, admonishment, advice, exhortation, reproof, and censure) 'speak from above, as it were', a lot of consideration should be put into examining the relationship of the persons involved. ${ }^{69}$ Especially tricky were situations in which an 'equal admonishes equal, or one of inferior standing advises one superior to him', in which cases 'a more diplomatic tone' was needed. ${ }^{70}$ Moreover, the bulk of the analysis offered advice precisely for those contexts in which one addressed princes and those high up in the hierarchy. In political counsel, as it was outlined in De consultatione, the management of social situations through decorum was also the key. In fact, the whole point of Vives's handbook was to shift the focus of deliberative rhetoric from the analysis of a question to the social dynamics of the situation. Classical advice on deliberations always dealt with the analysis of a political question under debate (e.g. concerning a future war) through the categories of the honest and the expedient, but this was a minor issue in Vives's manual. ${ }^{71}$ It rather focused on how to approach the prince in the spirit of modesty without activating negative emotions in him. Indeed, the combination of an analysis of the recipient with an explicit call for a rhetoric that would never openly break with the appearance of concord was precisely what decorum implied: persuasion within socially accepted standards tailored for one's audience.

\footnotetext{
${ }^{67}$ ASD I/2, pp. 325-7 (CWE 25, pp. 80, 81).

${ }^{68}$ Vives, De conscribendis, pp. 50-1, 56-9.

${ }^{69}$ Ibid., pp. 52-3.

${ }^{70}$ Ibid., pp. 52-5.

${ }^{71}$ For the classical tradition, see Ad Herennium, pp. 156-73 (3.2.2-3.5.9); Cicero, De inventione, trans., H. M. Hubbell, in Cicero, De inventione, De optimo genere oratorum, Topica (Cambridge, MA, 1949), pp. 1-346, at pp. 324-43 $(2.52 .157-2.58 .176)$.
} 
When Vives, in De ratione dicendi, offered the most extensive treatment of decorum of the time, he could gather discussions on the importance of audience for rhetorical choices, Erasmus's ideas on accommodation in religious rhetoric, and in-depth analyses of princely rhetoric under one concept. In bringing considerations of the audience together with an explicit call for decorum, De ratione dicendi argued that persuasion became possible only when decorum was respected and confrontation remained hidden. In doing so, it provided an answer to the divisiveness of language which Vives himself, in a 1535 criticism of the Anabaptist revolt in Münster, had linked to social violence. In De communione rerum (1535), he wrote that 'dissension of opinions' had led to 'discord in life', where verbal fight had resulted in actual violence through 'spears, swords, cannons'. ${ }^{72}$ In De ratione dicendi, decorum regulated socially acceptable speech by linking it to erudite humanist Latin, which, for Vives, secured that hierarchies were acknowledged, confrontation was avoided, strong passions suppressed, and discord was not advanced. In this way, decorum embedded persuasive speech and the mastery of the emotions of one's audience in non-adversarial rhetoric.

$\mathbf{V}$

While there are differences between different manuals written in different moments for different purposes, I have argued that Erasmus and Vives shared common ideas about how rhetorical theory should be transformed. First, against the formulaic tradition they began to argue that, while general precepts could be given, it was more important to think about the particularities of the situation with a specific focus on the audience/recipient. Second, they both maintained, especially in their mature writings on rhetorical theory, that in most cases a decorous speech that hid open confrontation was

\footnotetext{
${ }^{72}$ Mayans, p. 8:465 (De communione rerum): 'Ex dissensione opinionum ventum est ad dissidium vitae, coeptum est non jam ampliis linguis et calamis certari, sed hastis, gladis, bombardis'. The translation is mine.
} 
the best way to address one's audience, especially when one addressed a superior. As a combination of these ideas, they came to think that one's assessment of the particularities of any given situation, especially the audience, was central to what could be considered decorous speech in a specific occasion. This approach to rhetoric was widely disseminated. While Vives's De ratione dicendi, with its message emphasizing decorum, was not printed very often, it condensed under one concept several ideas on persuasive speech, which were explicitly treated in Erasmus's and Vives's popular letterwriting manuals, in discussions on Ciceronianism, in reflections on counsel, in expositions on the decorum of the Bible and St. Paul, and in handbooks on preaching (Ecclesiastes). ${ }^{73}$

There are significant developments in the internal history of rhetoric that can be better understood if read in the context of rhetorical decorum. As Lawrence Green has argued, one of the broad developments of the $15^{\text {th }}$ and $16 \mathrm{~h}$ centuries was the reincorporation of Aristotle's theory of emotions - a central part of his Rhetoric - into rhetorical theory. ${ }^{74}$ For Green, Vives was a major figure in this process. Indeed, Vives frequently claimed in De ratione dicendi that rhetoric was ultimately based on an understanding of the functions of the soul (especially emotions), and his treatise on the soul, De anima et vita (1538), provided a description of the kind of emotional dispositions that served as the basis for the analysis of one's audience/recipient in rhetoric. When one sees the centrality of the audience for Erasmian rhetoric, the incorporation of an Aristotelian analysis of emotions (or some variant based on it) into rhetorical theory becomes much more understandable. What is more, De anima, with its analysis of emotions such as pride or envy, gave theoretical depth to a central implication of decorum, according to which difference of opinion should not be apparent.

But, as I have sought to argue, decorum should also be understood as an answer to diverse problems not directly related to the internal history of rhetoric. As a call for non-conflictual

\footnotetext{
${ }^{73}$ For Vives's reception, see Valentín Moreno Gallego, La recepción hispana de Juan Luis Vives (Valencia, 2006); González González, Una república.

${ }^{74}$ Lawrence D. Green, ‘Aristotle's rhetoric and Renaissance views on the emotions', in Peter Mack, ed., Renaissance rhetoric (London, 1994); Mack, Renaissance rhetoric, p. 170.
} 
speech, it certainly played a part in a broader early-modern interest in civil speech and behaviour. Ever since Norbert Elias's The Civilizing Process, several historians have pointed out that codes of civility, reserved predominantly for restricted contexts in the Middle Ages (e.g. the monastery), were generalized to cover a much wider range of social relationships in the early modern period and that Erasmus was a key figure in this process. ${ }^{75}$ But while decorum could be discussed in the more general context of manners in works such as Erasmus's De civilitate morum puerilium (1530), rhetorical decorum, as a specifically conversational virtue, also addressed specific problems dealing with acceptable speech.

As a conversational virtue, decorum was an attempt to regulate speech in the highly conflictual atmosphere of the early $16^{\text {th }}$ century where the nascent pamphlet culture was beginning to transform the logic of discussion. Its role in creating stability and harmony is most clearly apparent in the domain of religious debate. In the past few decades, several studies have connected the Reformation with the communicative possibilities of the printing press, which invited new audiences to judge on fundamental theological questions previously reserved for the selected few. The discussion of the 1520 s, often conducted through pamphlets, has frequently been described as polemical and divisive. The pamphlet culture of the period has also been seen as a prelude to what has been sometimes called the post-Reformation public sphere where public verbal antagonism was a natural extension of religious division and violence in a series of conflicts culminating in the English Civil War. ${ }^{76}$

In the context of the fierce religious and dynastic polemic of the $1520 \mathrm{~s}$, the idea of decorum, as it was outlined by Erasmus and Vives, was at the heart of a call for more conversational civility, which, as Teresa Bejan has recently argued, was to become a common reaction to the

\footnotetext{
75 Thomas, Civility, p. 18; Roger Chartier, The cultural uses of print in early modern France (Princeton, 1987), pp. 769.

${ }^{76}$ Jesse Lander, Inventing Polemic (Cambridge, 2006), pp. 6-19; Peter Lake - Steven Pincus, 'Rethinking the Public Sphere in Early Modern England', Journal of British Studies, 45:2 (2006), pp. 270-92.
} 
divisiveness of speech throughout the early modern period ${ }^{77}$ In Erasmus, decorous discussion was a central part of his answer to the problem that the highly polemical tone of Luther and many of his followers posed to the unity and concord of the Church. By broadening the category of non-essentials of faith (adiaphoric questions) on which difference of opinion was to be tolerated, by forbearing outright error, and by resorting to decorum in religious dialogue, Erasmus aspired to guarantee the unity of the Church in the future. The Erasmian model has been seen as central for the development of various positions on religious dialogue both within and outwith Europe. In Europe, several irenic thinkers, with their emphasis on peace and concord, drew on the model of civil conversation, and the organization of a number of colloquies, which aspired to reunite Christendom, were indebted to the Erasmian ideal of decorous conversation. ${ }^{78}$ Outside Europe, the case of the Jesuits is a notable one. The Jesuits, the most developed educational culture of Catholic Europe in the later $16^{\text {th }}$ and $17^{\text {th }}$ centuries, largely adopted Erasmus's reading of St. Paul, which emphasized his ability to become all things to all people in order to save them (1. Corinthians, 9:19-23). The quote was important in the development of a theory of accommodation, according to which the truth of Christianity had to be adjusted to the languages and cultures of non-Christians around the world. ${ }^{79}$ Just like decorum prescribed, the idea was to temporarily forebear the errors of one's audience and to talk about truth by appealing to what was positively valued by the audience and without activating negative emotions towards the speaker and his message.

Yet, as I have argued, decorum was of considerable significance in politics as well. One aspect here, similarly to religious discussion, was certainly the ability of decorum to enhance stability. In stressing the harmful potential of strong passions and conflict, the principles of decorum were in a marked contrast to much of political speech based on dynastic confrontation, which, for Vives and

\footnotetext{
77 Teresa M. Bejan, Mere Civility (Cambridge, MA, 2017), pp. 8-11, 20-49.

${ }^{78}$ Remer, Humanism, pp. 103-5; Benjamin J. Kaplan, Divided by Faith: Religious Conflict and the Practice of Toleration in Early Modern Europe (Cambridge, MA, 2007), pp. 127-43.

${ }^{79}$ Casanova - Banchoff, eds., The Jesuits and globalization: historical legacies and contemporary challenges (Washington DC, 2015), pp. 7-8.
} 
Erasmus, nurtured warfare and political division. ${ }^{80}$ Yet its potential to avoid conflict was not an end in itself; decorum had deep roots in humanist rhetoric, which emphasized the importance of convincing speech as a realization of the duties of an active life.

Historians have often interpreted the rise of more civil discursive codes as an abandonment of humanist ideals of active virtue and as a move towards a world of manners, reciprocal pleasing, and social distinction. The transition from civic virtue to politeness was famously associated with the rise of commerce in the $18^{\text {th }}$ century by John Pocock, but others have emphasized the Renaissance as a key moment in the development of the opposition between refined manners and civic virtue, and interpreted decorum in this context. ${ }^{81}$ But, as I have argued, Erasmus and Vives did not understand decorum as part of civility that was emptied of civic potential. Both consistently emphasized the importance of putting all of one's knowledge at the service of the community. While this demand, in such works as Vives's De disciplinis, was not merely intended for a Ciceronian citizen of a specific polity, but rather for a Stoic-Christian humanist, who could work for the common good in different environments (education, religion, administration), one of its possible realizations was to serve as a counsellor. ${ }^{82}$ In counsel, rhetoric was intrinsically linked with the duty to serve the common good through the eloquent and appropriate use of words. Indeed, it is precisely because of the stress put on virtue and the common good that the relationship between decorum and broader notions of courtly manners was problematic. Unlike Italian manuals, such as Baldassare Castiglione's The Book of the Courtier (Il cortegiano, 1528), which underscored the importance of interiorizing a code of courtly conduct (e.g. dancing, hunting), Erasmus and Vives were suspicious of the potential of power to corrupt, with Vives, in De disciplinis, denouncing most of the activities of a courtier. ${ }^{83}$ While this

\footnotetext{
${ }^{80}$ See Mayans, pp. 5:288 (De concordia).

${ }^{81}$ John Pocock, Virtue, Commerce, and History (Cambridge, 1985), pp. 49-50, 115; Bryson, Courtesy, pp. 44-6, 181.

${ }^{82}$ Vives, De disciplinis, pp. 469-72.

${ }^{83}$ Ibid., pp. 477.
} 
humanist rhetoric of decorum did not possess all the flexibility of an Italian cortegiano, it was meant to enable a humanist life of negotium in a changed, monarchical environment.

The model outlined above reinforces and gives new depth to those interpretations that have shown how classical rhetoric, with its participatory and civic ideals, continued to strive in the strictly hierarchical and predominantly monarchical context of the early modern period. These interpretations, most clearly articulated in Quentin Skinner's work, have emphasized that, even in contexts where deliberative institutions were absent, rhetorical education and culture continued to portray the art of eloquence as a form of civil science (scientia civilis) or political practice. ${ }^{84}$ Through decorum, one can enrich this view by showing how the civic element was deliberately appropriated to a monarchical context; readers of rhetorical treatises were taught to address those in power in the spirit of decorum in order to talk about political matters. In this picture, civil speech is not the denial of civic virtue but its very condition of possibility in a changed world.

Projects are of course different from processes of reception. It is evident that ideas linked to rhetorical decorum, the centrality of audience, and political counsel became important in the later $16^{\text {th }}$ century. Popular Catholic handbooks on rhetoric, such as Cypriano Soarez's (15241593) De arte rhetorica (1560), often began to dedicate sections to the audience/recipient in deliberations. ${ }^{85}$ Others included presentations on decorum, and in Nicolas Caussin's (1583-1651) massive De eloquentia sacra et humana (1619) Vives was named as an authority on the matter. ${ }^{86}$ Advice concerning decorum in addressing the prince can also be found; in 1582, Marc-Antoine Muret (1526-1585), a leading French humanist, claimed that those who wrote 'letters well ... with prudence, and taking into account things, persons, and circumstances may easily reach the intimacy of Princes' ${ }^{87}$ The precise role played by Erasmus's and Vives's widely-disseminated manuals would,

\footnotetext{
${ }^{84}$ Peltonen, Rhetoric, p. 2; Skinner, Reason.

${ }^{85}$ Cypriano Soarez, De arte rhetorica (Sevilla, 1569), fols. $21^{\mathrm{r}}-22^{\mathrm{v}}$.

${ }^{86}$ Nicolas Caussin, De eloquentia sacra et humana (Paris, 1657), pp. 145-6. For John Rainolds's use of Vives's conception of decorum, see Pender, 'Prudence', pp. 363-5.

${ }^{87}$ In Fumaroli, 'Rhetoric', p. 258.
} 
of course, require a study of its own and it is very possible that their advice on decorum could be combined with a variety of approaches to political life (such as the Italian courtly tradition). Still, the popularity of their rhetorical works indicates that they might have played an important role in a process in which the persuasive potential of decorum was extensively explored throughout the early modern period before it was later emptied of its rhetorical powers and increasingly associated with sociability and politeness in the later $17^{\text {th }}$ and $18^{\text {th }}$ centuries. 